\title{
STUDY OF ANTIRETROVIRAL MUTANTS IN HIV PATIENTS WITH TREATMENT FAILURES AND THE EFFECT OF RISK FACTORS IN THE VIROLOGICAL FAILURES
}

\author{
Lizeth TAYLOR-CASTILlo(1), Gisela HERRERA-MARTínEZ(2), María Paz LEÓN-BRATTI(3), Ricardo BOZA(4), Bernal LEÓN-RODRÍGUEZ(1), \\ Ronald B. LUFTIG(1) \& Kirsten VISONÁ(1)
}

\begin{abstract}
SUMMARY
Introduction: Information about HIV phenotypes of resistant to available ART and the influence of different risk factors on virological failures (VF) in Costa Rican HIV positive patients prior or during HAART is unknown.

Materials and methods: Eighty nine samples, $72 \mathrm{VF}$ and 17 basal (before treatment) were analyzed by examining resistant mutants in reverse transcriptase (RT) and protease (PT) regions using Trugene or LIPA genotyping kits. Sixty eight control patients were selected and relevant information was collected in a questionnaire.

Results: Poor adherence, presence of resistant mutations and number of treatment's changes were the only significant factors found ( $p=0.006,0.04$ and 0.01 respectively). From 66 sequenced samples, 78\%, 50\% and 50\% showed resistance to NRTI (nucleoside reverse transcriptase inhibitors), NNRT (non-nucleoside reverse transcriptase inhibitors) and PI (protease inhibitors), respectively. The most frequent mutations were M41L, M184V, and T215FY in RT and L62PI, L10FIRV and M36I in PT.

Discussion: The most important factor related to treatment response in this study was adherence to treatment. Mutations in RT were related to the treatment failure while the ones found in PT were secondary mutations which have been previously described to influence the selection of primary resistance mutations in these regions. The study reveals the urgency to detect resistant mutations in VF to be considered by physicians for selection of treatment schedule, to analyze basal HIV patients for monitoring of the spread of resistant mutations and the importance to reinforce the adherence in the patients for overall treatment outcome.
\end{abstract}

KEYWORDS: Human immunodeficiency virus; Anti-retroviral treatment; Resistance mutations; Highly active antiretroviral therapy; Risk factors; Response; Adherence.

\section{INTRODUCTION}

An estimated of 40 million people are infected with HIV/AIDS in the world, $90 \%$ in developing countries and of these five to six million are in need of anti-retroviral treatment (ART) $)^{11,19}$. ART reduces morbidity and mortality associated with HIV infection and enhances recovery of impaired immunologic function in most cases. However, these drugs also increase the possibility of developing resistance in patients with incomplete viral suppression ${ }^{9,11,16,17,19}$. Furthermore, ART is often not available in developing countries due to its high cost, a situation that was declared a global health emergency by the World Health Organization (WHO). Thus, in 2001 a partnership was launched between United Nations organizations and six major pharmaceutical companies in order to lower the prices of ART in developing countries which participated in the accelerated access initiative (AAI) ${ }^{19}$.
There is extensive documentation about development of mutants resistant to highly active antiretroviral therapy (HAART), as well as its occurrence in certain individuals before treatment. Important factors that influence the development of mutations include: poor patient compliance, high initial viral load, low basal $\mathrm{CD}_{4}$ levels, HIV subtype, co-infections with other agents, sub optimal drug levels and interaction with other drugs that would affect absorption, elimination and adverse reactions ${ }^{2,5,15,26,30}$.

In Costa Rica, the Social Security System (SSS) initiated HAART in 1997 with universal coverage in all the country, and approximately 1800 patients are under treatment at the present time. This situation represents a high cost for the SSS.

Virological failure (VF) is a reality accompanying ART and requires

(1) Louisiana State University, International Center for Medical Research and training, San José, Costa Rica.

(2) Calderón Guardia Hospital, Social Security, San José, Costa Rica.

(3) México Hospital, Social Security, San José, Costa Rica.

(4) San Juan de Dios Hospital, Social Security, San José, Costa Rica.

Grant support: Florida Ice and Farm, Costa Rica. Louisiana State University-International Center for Medical Research and Training (LSU-ICMRT).

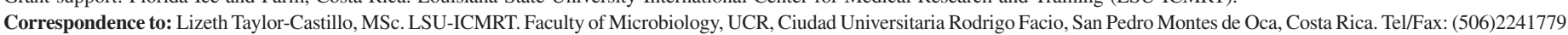

E-mail: icmrtlsu@racsa.co.cr or lizethtaylor@yahoo.com 


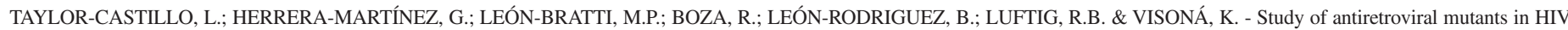
patients with treatment failures and the effect of risk factors in the virological failures. Rev. Inst. Med. trop. S. Paulo, 47(6):327-331, 2005.

prompt detection and characterization of associated resistant mutants, in order to change the treatment to the most suitable scheme and stop accumulation of more mutants that could jeopardize treatment outcome. The test of drug resistance is highly recommended and even more so in developing countries where, drug options, monitoring tools, and alternative therapeutic schemes are limited ${ }^{6,9,13,23}$.

Sequence-based genotyping assays to determine ART resistant mutants have been developed by different commercial companies. These assays are complex, requiring careful technical performance and data interpretation, consistent test procedures and strict quality control to ensure reliable results. The understanding of the characteristics, limitations of the assay and complexity of resistance patterns is required for a consequent and trusty interpretation of drug test results $\mathrm{s}^{6,10,14,25}$.

In Central America there are no published studies defining the degree of HIV diversity and the existence of phenotypes resistant to available ART.

The aim of this study was to detect and characterize ART resistant mutants in Costa Rican HIV positive patients prior or during HAART and with VF, to analyze the influence of different risk factors on the appearance of VF, as well as to evaluate the benefits of using resistant mutant information in order to choose an adequate treatment regimen.

\section{MATERIALS AND METHODS}

Study population: A total of 89 patients were selected from the SSS in Costa Rica during 2003, 72 from patients receiving HAART with VF and 17 basal samples from patients before treatment. VF was defined as an increase of viral load of $\geq 1 \times 10^{3}$ copies $/ \mathrm{mL}$ in two consecutive samples (Infectology Committee Criteria, SSS). A blood sample was collected from each patient (VF and basal) and the plasma was referred to the International Center of Medical Research and Training (ICMRT) and kept frozen below $-40{ }^{\circ} \mathrm{C}$ until analyzed.

In addition 68 HIV infected individuals with HAART and without VF were selected as controls, matched in age and period of treatment.

Data collection: Each patient signed a consent form and a questionnaire was completed for each patient and control, based on the clinical record with the following information: HIV viral load (copies $/ \mathrm{mL}$ ), $\mathrm{CD}_{4}$ count (cells $/ \mathrm{mm}^{3}$ ), sex, age, place of residence, risk group (men who have sex with men, heterosexual, intravenous drug users), clinical presentation (AIDS, AIDS associated complex (ARC), asymptomatic), treatment initiation date, type of treatment, opportunistic infections, depression (yes or no), education level (no education, primary, secondary and university education), occupation (professional, technical businessman, manual worker, housewife), alcohol consumption (yes or no), use of illicit drugs (type of drug), adherence (good or bad, good adherence was defined as over 95\% compliance with the prescribed regimen), type and change of treatment.

Methods: A total of 89 samples (72 VF and 17 basal) and the 68 samples of control group, were analyzed by viral load using the kit Amplicore HIV-1 version 1.5 (Roche, USA) according to manufacturer's instructions. Each sample from a patient with VF was sequenced by the method of Trugene and basal samples analyzed using
LIPA. Both methods permitted the detection of resistant mutants of the HIV RT and PT.

RNA Extraction, RT-PCR and sequencing: RNA was extracted from $1 \mathrm{~mL}$ of previously centrifuged $\left(23,500 \mathrm{x}\right.$ g for $1 \mathrm{~h}$ at $\left.8{ }^{\circ} \mathrm{C}\right)$ plasma samples, using a silica gel system QIAamp Viral RNA mini kit (Qiagen Inc, CA.). An RT-PCR of pol. gene of HIV was done and after sequenced for both the RT and PT region of interest with the Trugene HIV-1 Genotyping Kit (Visible Genetics, Canada) according to manufacture's instructions. Sequences analysis was performed using the Gene Open System and the VG Gene Librarian HIV Module, version 3.1.6 ${ }^{6}$ (Visible Genetics, Canada).

Analysis of basal samples was done by LIPA, courtesy of Innogenetics, Inc., at Gent, Belgium ${ }^{23}$.

Statistical Analysis: Analysis of the different variables was carried out using SPSS software. The $\mathrm{X}^{2}$ test with an $\alpha$ value of less than 0.05 was defined as significant. A logistic regression was used to identify the most important variables associated to VF.

\section{RESULTS}

Patients with VF were predominantly males (88.4\%), 64.5\% were men who have sex with men and $89 \%$ were between 21 and 50 years old. Of these patients $46 \%$ had basal viral load of $\geq 10^{5}$ copies $/ \mathrm{mL}$ and $56 \%$ showed a basal $\mathrm{CD}_{4}$ count $<200$-cells $/ \mu \mathrm{L}$.

The level of $\mathrm{CD}_{4}$ in the last samples, was $>200$ cells $/ \mu \mathrm{L}$ in $94 \%$ of the control group and $70 \%$ of VF patients; with mean values of 551 and 343.75 cells $/ \mu \mathrm{L}$, respectively. The mean basal $\mathrm{CD}_{4}$ level in control and $\mathrm{VF}$ patient was 189.8 and 166.8 cells/ $\mu \mathrm{L}$ respectively. All controls had viral loads $<10^{3}$ copies $/ \mathrm{mL}$; in contrast only $7 \%$ of the VF patients $(\rho \leq 0.000)$ with mean values of $<50$ copies $/ \mathrm{mL}$ and $1.3 \times 10^{5}$ for each group, respectively (Figs. 1 and 2). The mean basal viral load was 1.8 $\mathrm{x} 10^{5}$ for the VF patient and $1.67 \times 10^{5}$ for the control group.

Also, $68.7 \%$ of VF patients were clinically diagnosed as AIDS or ARC compared to only $17.7 \%$ in the control group.

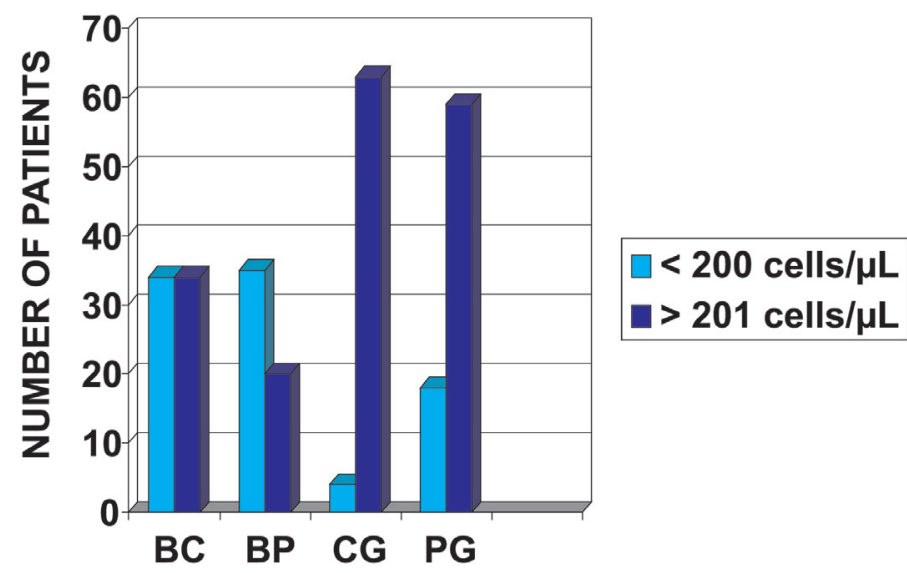

Fig. 1 - $\mathrm{CD}_{4}$ level in 68 basal samples of the control group (BC), 55 basal samples of the VF patient (BP), 67 last sample in the control group (CG), and 67 last sample in the VF patient (PG), analyzed during 2003. 


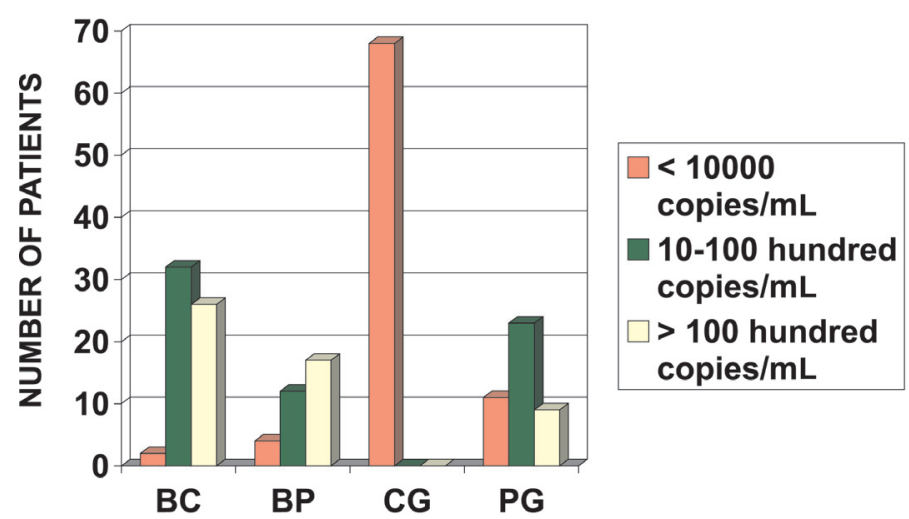

Fig. 2 - Viral load in 60 basal samples of the control group (BC), 33 basal samples of the VF patient (BP), 68 last sample in the control group (CG), and 43 last sample in the VF patient (PG), analyzed during 2003.

Of the risk factors analyzed, the following were found to be associated with VF: poor adherence, history of depression, occupation (no professional or technical), low education level, alcohol ingestion, clinical presence of AIDS and/or ARC, type of initial ART, presence of resistant mutants and the number of change of treatment (Table 1). This association persisted only for poor adherence, presence of resistant mutants and the number of change of treatment after a logistic regression analysis ( $p=$ $0.006,0.04,0.01$ respectively). The OR to adherence was 63.5 (3.11269.1; CI 95\%), to change of treatment was 44.1 (2.4-809.5; CI 95\%) and $11.4(1.0-129.1$; CI 95\%) to resistant mutants.

Table 1

Association between virological failure (VF) and risk factors

\begin{tabular}{llll}
\hline Factor & $\begin{array}{l}\text { Control } \\
\text { group }(\%)\end{array}$ & $\begin{array}{l}\text { Patients } \\
\text { group (\%) }\end{array}$ & $p$ value \\
\hline Adherence & $52 / 53(82.5)$ & $11 / 59(17.5)$ & 0.000 \\
$\begin{array}{l}\text { Depression } \\
\text { Professional or technical }\end{array}$ & $\begin{array}{l}17 / 28(37) \\
29 / 63(63)\end{array}$ & 0.015 \\
University education & $26 / 43(59)$ & $14 / 60(32)$ & 0.003 \\
Ingestion of alcohol & $24 / 53(41.4)$ & $34 / 52(58)$ & 0.03 \\
Initial viral load & & & 0.04 \\
$>$ 104 copies/mL & $58 / 60(67)$ & $29 / 33(33)$ & $0.10^{*}$ \\
AIDS or ARC & $11 / 62(20)$ & $44 / 64(80)$ & 0.000 \\
$\begin{array}{l}\text { Initial zidovudine, } \\
\text { lamivudine, Indinavir }\end{array}$ & $45 / 71(60)$ & $30 / 68(40)$ & 0.023 \\
Initial zidovudine, & & & \\
lamivudine, nelfinavir & $10 / 71(28.6)$ & $25 / 68(71.4)$ & 0.002 \\
Resistance mutation & $4 / 12(7)$ & $54 / 62(93)$ & 0.000 \\
Change of treatment & $25 / 71(28.7)$ & $62 / 71(71.3)$ & 0.000 \\
\hline
\end{tabular}

* No significative

The $60 \%$ of the patients showed good response to zidovudine, lamivudine, indinavir but only $29 \%$ to zidovudine, lamivudine, nelfinavir. When analyzing the adherence, a higher level was found when using indinavir vs. nelfinavir.

Of 72 samples analyzed for ART resistant mutants only 66 could be amplified. In these samples resistance to at least one family of antiretroviral drugs was observed: 51 samples (78\%), showed resistance to NRTI, $33(50 \%)$ to NNRT and $33(50 \%)$ to PI. A mixture of resistance mutants to NRTI and PI was observed in $49 \%$ of the samples and $24 \%$ presented at least one resistance to each of the three types of drugs.

The frequency of mutations related to partial or total resistance to one or more ART is shown in Table 2. The three most frequent mutations for RT were M41L, M184V, and T215FY. These mutations were previously described to cause resistance to zidovudine, lamivudine, abacavir, didanosine, stavudine and zalcitabine ${ }^{28,29}$. However, the three highest frequencies of PI mutations observed in the samples were L63PI, L10FIRV, M36I; these mutations contribute to resistance only when other mutations are present ${ }^{20,24}$. Of all the mutations, D67N, K103 N, M184V, in RT and L10FIRV, M46IL, L63PI, and A71TV in PI showed a significant association with VF in this study ( $\mathrm{p}=0.03,0.013,0.002,0.028,0.033$, 0.009 , and 0.041 , respectively), when present alone or in combination with other mutations. This association disappeared when a logistic regression analysis was done with all the mutation together.

Table 2

Distribution of different mutations to RT and PT in the $66 \mathrm{VF}$ patient samples (PS) and in 17 basal samples (BS), collected during 2003

\begin{tabular}{lcccc}
\hline Mutation & $\begin{array}{c}\text { RT-PS } \\
(\%)\end{array}$ & $\begin{array}{c}\text { RT-BS } \\
(\%)\end{array}$ & $\begin{array}{c}\text { PT-PS } \\
(\%)\end{array}$ & $\begin{array}{c}\text { PT-BS } \\
(\%)\end{array}$ \\
\hline M41L-L63PI & $31(47)$ & $4(23)$ & $38(57)$ & $3(18)$ \\
M184V-L10FIRV & $28(42)$ & $1(6)$ & $21(32)$ & - \\
T215FY-M36I & $25(38)$ & $3(18)$ & $18(27)$ & $1(6)$ \\
K103N-A71TV & $23(35)$ & $1(6)$ & $18(27)$ & - \\
D67N-M46IL & $21(32)$ & - & $16(24)$ & - \\
K219EQ-N88DS & $14(21)$ & - & $15(23)$ & - \\
L210W-L90M & $13(20)$ & $1(6)$ & $13(20)$ & - \\
L74V-D30N & $11(17)$ & $2(12)$ & $9(14)$ & - \\
K70R-I54LTV & $11(17)$ & - & $8(12)$ & - \\
L100I-V82AT & $8(12)$ & - & $7(11)$ & $1(6)$ \\
V179DE-K20MR & $7(11)$ & - & $7(11)$ & - \\
K101EQ-L24I & $7(11)$ & - & $2(3)$ & - \\
V118I-I84V & $7(11)$ & - & $2(3)$ & - \\
V75ITV-V32I & $5(8)$ & $1(6)$ & $1(2)$ & - \\
V108I-L33F & $5(8)$ & & $1(2)$ & - \\
G190AS-I47V & $4(6)$ & - & $1(2)$ & - \\
Y188L-G48V & $3(5)$ & $1(6)$ & $1(2)$ & - \\
E44D & $2(3)$ & - & - & - \\
T69D & $2(3)$ & - & - & - \\
Q151M & $2(3)$ & - & - & - \\
P225H & $2(3)$ & - & - & - \\
F77I & $1(2)$ & - & - & - \\
A98G & $1(2)$ & - & - & - \\
\hline
\end{tabular}

In the basal sample four of 14 samples could be sequenced showing the mutation M41L and two of them showed two or three more mutations associated with drug resistance.

\section{DISCUSSION}

The study population was mainly comprised of men who have sex with men and was compared with basal samples from the study groups 


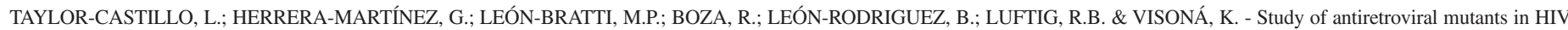
patients with treatment failures and the effect of risk factors in the virological failures. Rev. Inst. Med. trop. S. Paulo, 47(6):327-331, 2005.

(control and VF patients); both showed high viral load and low $\mathrm{CD}_{4}$ in basal samples, as has been observed in overall HIV positives population in Costa Rica (HIV Control Department, Ministry of Health, Costa Rica).

A measurement of plasma HIV-1 viral load is included in the standard care procedure for management of all HIV-1 infected individuals. This determination provides prognostic information for a more efficacious therapeutic intervention. However, treatment failure occurs and is influenced by several risk factors; the most important one in this study was patient compliance to the ARV drugs in use.

The assays used to detect mutations (Visible Genetics) are customer friendly, provide reliable and reproducible results; however, personnel training is an extremely important requirement. The software was very reliable too, although the editing process as well is also very important $^{10,12,14 .}$.

In this study no relationship was found between the outcome of treatment and the basal $\mathrm{CD}_{4}$ levels or basal viral loads in opposition to other studies ${ }^{2,12,16,22}$. Earlier data collected in 1998 at the beginning of HAART in Costa Rica (unpublished), showed no relationship between basal viral load and outcome of ART $(r=0.272)$, but an association was observed with the basal $\mathrm{CD}_{4}$ levels $(\mathrm{r}=0.045)$. In that study most of the VF were probably related to adherence, and other factors like clinical presentation, ART access and for all these factors, the existence of multiple resistant mutants that could not be taken into consideration due to absence of genotyping analysis before treatment changes.

The fact that more patients were adherent with zidovudine, lamivudine and indinavir than zidovudine, lamivudine and nelfinavir was controversial since indinavir treatment is relatively more difficult to comply, and it causes more severe secondary effects. However, indinavir is a more potent drug than nelfinavir and that may be the reason for patients under this drug to have a better outcome ${ }^{18,31,32}$.

The most frequent mutations found in the RT in this study (Table 2), cause total or partial resistance to zidovudine, stavudine, lamivudine, didanosine, zalcitabine, and abacavir ${ }^{28,29}$. It is noteworthy that the three first drugs mentioned above were included in the initial triple treatment scheme of these patients. The NNRT resistant prevalence was $43 \%$, with mutants L103 N present in $31 \%$ of the samples showing drug resistance to all three NNRT drugs used ${ }^{7,24}$.

The mutations, D67N, K103 N, M184V, in RT and L10FIRV, M46IL, L63PI, and A71TV in PI showed a significant association with VF in this study, however, in order to disclose the importance of these mutations a logistic regression analysis was done and the loosing of significance found, showed that all mutations are interrelated, therefore it is not possible to establish the difference in weight of each one in the VF.

The study showed that very few resistant mutants to HIV antiviral drugs were detected on basal samples in this population (Table 2) and the ones present did not condition the outcome of treatment.

In summary, there seems to be an urgent need to detect resistant mutants, whenever there is a treatment failure, to guide the physician

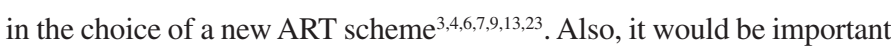
to reevaluate the "basal status" of patients going into HAART because with its use during many years, the HIV positive population can accumulate resistant mutants, which could interfere with the outcome of initial treatment ${ }^{3,4,20,21,27}$. However, mutations associated to resistance were found only in two of 11 basal samples taken during 2003 and sequenced during this year (data not shown).

By far, as noted the most important factor related to treatment response was adherence, in agreement to other studies ${ }^{2,5,15,26,30}$. Therefore physicians should consider adopt a more aggressive approach to improve the level of ARV drug adherence as a way to obtain a better treatment outcome.

\section{RESUMEN}

Estudio de mutantes resistentes a los antiretrovirales en pacientes con VIH con falla terapeutica y efecto de los factores de riesgo en el tratamiento

En Costa Rica no se tiene información a cerca de genotipos de resistencia para los tratamientos anti-retrovirales disponibles y la influencia de diferentes factores de riego en la falla virológica (FV) de pacientes VIH positivos previo o durante su tratamiento.

Ochenta y nueve muestras, $72 \mathrm{FV}$ y 17 basales, fueron analizadas con Trugene o LIPA para la detección de mutantes de resistencia en la transcriptasa reversa (TR) y en la proteasa (PT) del VIH. Se seleccionaron sesenta y ocho controles y se recolectó información relevante en un cuestionario.

La mala adherencia, la presencia de mutaciones y el número de cambios de tratamiento fueron los únicos factores con significancia encontrados. ( $p=0.03,0.04$ and 0.04 respectively). De 66 muestras secuenciadas, $78 \%, 50 \%$ y $50 \%$ mostraron resistencia a los inhibidores análogos y no análogos de nucleótidos para la TR y la PT respectivamente. La mutaciones más frecuentes fueron M41L, M184V, y T215FY en la TR y L62PI, L10FIRV y M36I en la PT.

La adherencia fue el factor más importante relacionado con la respuesta al tratamiento. Las mutaciones encontradas en la TR estaban relacionadas al tratamiento mientras que las de la PT fueron mutaciones secundarias que propician la aparición de las mutaciones asociadas a resistencia en esa región. Este estudio revela la necesidad de detectar mutantes de resistencia en pacientes con FV y de estudiar las muestras basales. Además la importancia de reforzar la adherencia en los pacientes para una mejor respuesta al tratamiento.

\section{ACKNOWLEDGEMENTS}

The authors thank Mr. Alfredo Sanabria, Ms Gabriela Solano, Dr. Antonio Solano, Lic. Mayra Brenes, and Dr. Oscar Solano from The Costa Rica Social Security System, for their collaboration in this study and Carlos Vargas and Ms Virgina Larrad from LSU-ICMRT, for technical assistance and supporting the preparation of the manuscript respectively. This work received financial support from the Florida Ice and Farm from Costa Rica. 


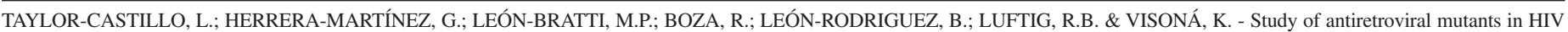
patients with treatment failures and the effect of risk factors in the virological failures. Rev. Inst. Med. trop. S. Paulo, 47(6):327-331, 2005.

This work is part of the requirements to obtain the $\mathrm{PhD}$ degree in the PhD Science Program in University of Costa Rica for the first author.

\section{REFERENCES}

1. ALEXANDER, C.S; ASSELIN, J.J.; TING, L.S. et al. - Antiretroviral concentrations in untimed plasma samples predict therapy outcome in a population with advanced disease. J. infect. Dis., 188: 541-548, 2003.

2. CASCADE COLLABORATION - Determinants of survival following HIV-1 seroconversion after the introduction of HAART. Lancet, 262: 1267-1274, 2003.

3. CLEVENBERGH, P.; DURANT, J.; CHAILlOU, S. \& DELlAMONICA, P. - HIV drug resistance and insufficient drug plasma levels as factor determining antiretroviral treatment failure. AIDS Rev., 1: 1576, 1999.

4. DEEKS, S.G. - Treatment of antiretroviral-drug-resistant HIV-1 infection. Lancet, 362: 2002-2011, 2002.

5. DRAGSTED, U.B.; GERSTOFT, J.; PEDERSEN, C. et al. - Randomized trial to evaluate indinavir/ritonavir versus saquinavir/ritonavir in human immunodeficiency virus type 1-infected patients: The MaxCmin1 Trial. J. infect. Dis., 188: 635-642, 2003.

6. ERALI, M.; PAGE, S.; REIMER, L. \& HILLYARD, D.R. - Human immunodeficiency virus type 1 drug resistance testing: a comparison of three sequence-based methods. J. clin. Microbiol., 39: 2157-2165, 2001.

7. GALLEGO, O.; RUIZ, L.; VALLEJO, A. et al. - Rate of virological treatment failure and frequencies of drug resistance genotypes among human immunodeficiency viruspositive subjets on antiretroviral therapy in Spain. J. clin. Microbiol., 40: 3865 $3866,2002$.

8. GALLI, R.A.; SATTHA, B.; WYNHOVEN, B.; O' SHAUGHNESSY, M.V. \& HARRIGAN, P.R. - Sources and magnitude of intralaboratory variability in a sequence-based genotypic assay for human immunodeficiency virus type 1 drug resistance. J. clin. Microbiol., 41: 2900-2907, 2003.

9. GAZZARD, B.; MOYLE, G.; WEBER, J. et al. - British HIV association guidelines for antiretroviral treatment of HIV seropositive individuals. BHIVA Guidelines Coordinating Committee. Lancet, 349: 1086-1092, 1997.

10. GRANT, R.M.; KURITZKES, D.R.; JOHNSON, V.A. et al. - Accuracy of TRUGENE HIV-1 genotyping kit. J. clin. Microbiol., 41: 1586-1593, 2003.

11. HAMMER, S.M.; TÜRMEN, T.; VARELDZIZ, B. \& PERRIENS, J. - Antiretroviral guidelines for resource-limited settings: the WHO's public health approach. Nature Med., 8: 649-650, 2002.

12. HUANG, D.D.; ESHLEMAN, S.H.; BRANBILLA, D.J.; PALUMBO, P.E. \& BRENER, J.W. - Evaluation of the editing process in human immunodeficiency virus type I genotyping. J. clin. Microbiol., 41: 3265-3272, 2003.

13. JIANG, H.; DEEKS, S.G.; KURITZKES, D.R. et al. - Assessing resistance cost of antiretroviral therapies via measures of future drugs options. J. infect. Dis., 188: 1001-1008, 2003.

14. KURITZKES, D.R.; GRANT, R.M.; FEORINO, P. et al. - Performance characteristics of the TRUGENE HIV-1 genotyping kit and the Opengene sequencing system. J. clin. Microbiol., 41: 1594-1599, 2003.

15. LEDERGERBER, B.; EGGER, M.; OPRAVIL, M. et al. - Clinical progression and virological failure on highly active antiretroviral therapy in HIV-1 patients: a prospective cohort study. Lancet, 353: 863-868, 1998.

16. LEE, N.; HOGG, R.S.; YIP, B.; HARRIGAN, P.R. et al. - Rates of disease progression among human immunodeficiency virus-infected persons initiating multiple-drug rescue therapy. J. infect. Dis., 188: 137-141, 2003.
17. LITTLE, S.J.; HOLTE, S.; ROUTY, J.P. et al. - Antiretroviral drugs resistance among patients recently infected with HIV. New Engl. J. Med., 347: 385-394, 2002.

18. MEMBERS. AOL.COM/MJAYM/NEWS.HTML - Commonality news.

19. MOATTI, J.P.; N'DOYE, I.; HAMMER, S.M.; HALE, P. \& KAZATCHKINE, M. Antiretroviral treatment for HIV infection in developing countries: an attainable new paradigm. Nature Med., 9: 1449-1452, 2003.

20. PERNO, C.L.; COZZI-LEPRI, A.; FORBICI, F. et al. - Minor mutations in HIV protease at baseline and appearance of primary mutation $90 \mathrm{M}$ in patients for whom their first protease-inhibitor antiretroviral regimens failed. J. infect. Dis., 189: 1983-1987, 2004.

21. PIRES, L.I.; SOARES, M.A.; SPERANZA, F.A. et al. - Prevalence of human immunodeficiency virus drug resistance mutations and subtypes in drug-naive, infected individuals in the army health service of Rio de Janeiro, Brazil. J. clin. Microbiol., 42: 426-430, 2004

22. RIZZARDI, G.P.; DE BOER, R.J.; HOOVER, S. et al. - Predicting the duration of antiviral treatment needed to suppress plasma HIV-1 RNA. J. clin. Invest., 105: 777-782, 2000 .

23. SERVAIS, J.; LAMBERT, C.; FONTAINE, E. et al. - Comparison of DNA sequencing and line probe assay for detection of human immunodeficiency virus type $1 \mathrm{drug}$ resistance mutations in patients failing highly active antiretroviral therapy. $\mathbf{J}$. clin. Microbiol., 39: 454-459, 2001

24. SVEDHEM, V.; LINDKVIST, A.; LIDMAN, K. \& SONNERBORG, A. - Persistence of earlier HIV-1 drug resistance mutations at new treatment failure. J. med. Virol., 68: 473-478, 2002.

25. TORTI, C.; QUIROS-ROLDAN, E.; KEULEN, W. et al. - Comparison between rulesbased human immunodeficiency virus type I genotype interpretations and real or virtual phenotype: concordance analysis and correlation with clinical outcome in heavily treated patients. J. infect. Dis., 188: 194-201, 2003.

26. VAN VAERENBERGH, K.; VAN LAETHEM, K.; ALBERT, J. et al. - Prevalence and characteristic of multinucleoside-resistant human immunodeficiency virus type 1 among European patients receiving combination of nucleoside analogues. Antimicrob. Agents Chemother., 44: 2109-2117, 2000.

27. WEINSTOCK, H.S.; ZAIDI, I.; HENEINE, W. et al. - The epidemiology of antiretroviral drug resistance among drug-naive HIV-1 infected persons in 10 US cities. J. infect. Dis., 189: 2174-2180, 2004

28. WINTERS, M.A.; BOSCH, R.J.; ALBRECHT, M.A.; KATZENSTEIN, D.A. \& AIDS CLINICAL TRIALS GROUP 364 STUDY TEAM - Clinical impact of the M184V mutation on switching to didanosine or maintaining lamivudine treatment nucleoside reverse-transcriptase inhibitor-experienced patients. J. infect. Dis., 188: 537-540, 2003.

29. WhitCOMB, J.M.; PARKIN, N.T.; CHAPPEY, C.; HELLMAN, N.S. \& PETROPOULOS, C.J. - Broad nucleoside reverse-transcriptase inhibitor crossresistance in human immunodeficiency virus type I clinical isolates. J. infect. Dis., 188: $992-1000,2003$

30. WWW.ACRIA.ORG/TREATMENT/TREATMENT_EDU_DRUG_RESIST.HTML What are some of the factors that contribute to the accumulation of drug-resistance mutations during therapy?

31. WWW.PROJINF.ORG/WHATSNEWS/WN_9808.HTML - Project Inform's What's new? Memo August 1998 (HIV/AIDS Treatment Information).

32. WWW.THEBODY.COM/PINF/ESPANOL/DRUGID_SP.HTML - The body: Proyecto inform: cuadro de identificación de medicamentos.

Received: 7 October 2004

Accepted: 27 June 2005 